\title{
Petaloporella (Cryptostomata, Bryozoa) from the Lower Devonian of central Bohemia
}

\author{
ANDREJ ERNST
}

The bryozoan genus Petaloporella Prantl, 1935 was originally described from the Lower Devonian Braník Limestone (Zlíchovian = Lower Emsian) of Braník, the Czech Republic. It belongs to the family Hyphasmoporidae Vine, 1885. The type species Petaloporella bohemica Prantl, 1935 was also recorded from the Lower Devonian (Pragian) of Bohemia and Morocco. The present paper provides an emended diagnosis of the genus and a description of new Petaloporella bohemica material from the Koněprusy Limestone of Zlatý Kůn̆ near Koněprusy, the Czech Republic. - Key words: Lower Devonian, Bohemia, cryptostome Bryozoa, taxonomy.

ERNST, A. 2009. Petaloporella (Cryptostomata, Bryozoa) from the Lower Devonian of central Bohemia. Bulletin of Geosciences 84(4), 767-770 (1 figure, 1 table). Czech Geological Survey, Prague. ISSN 1214-1119. Manuscript received August 11, 2009; accepted in revised form September 22, 2009; published online December 29, 2009; issued December 31, 2009.

Andrej Ernst, Institut für Geowissenschaften der Christian-Albrechts-Universität zu Kiel, Ludewig-Meyn-Str. 10, D-24118 Kiel, Germany; ae@gpi.uni-kiel.de

Bryozoans are abundant and diverse in the Lower Devonian of central Bohemia, representing an important faunal component of reefs. The study of bryozoans began in the $19^{\text {th }}$ century, and up until now, 76 bryozoan species have been recorded from the Pragian to Emsian sequence of central Bohemia (see an overview in Ernst 2008 and Ernst \& May 2009). A few recent publications provide taxonomic descriptions of the bryozoan fauna from the Koněprusy Limestone (Pragian, Lower Devonian) of Zlatý Kůň near Koněprusy, the Czech Republic (McKinney \& Kříž 1986, Ernst 2008, Ernst \& May 2009).

Prantl (1935) described several bryozoan taxa including a new genus, Petaloporella, from the Lower Devonian Braník Limestone (Zlíchovian = Lower Emsian) of Braník, the Czech Republic. Unfortunately, his illustrations were not of a satisfactory quality, and the type material has since been lost. The morphology of Petaloporella therefore remained dubious (Blake 1983). Bigey (1994) described and figured a bryozoan, which she called "?hyphasmoporid", from the Lower Devonian (Pragian) of Morocco. This taxon shows all the morphological features characteristic of Petaloporella, and corresponds to the measurements of P. bohemica Prantl, 1935 presented here.
During the study of European bryozoan faunas, abundant material from the reefal limestone from the Konéprusy reef was examined. Several colonies of Petaloporella bohemica were discovered within a set of 111 thin sections. This material is described and illustrated here, an emended diagnosis for the genus Petaloporella is proposed and a neotype for $P$. bohemica erected.

\section{Material and methods}

The material for the present study comes from the upper Koněprusy Limestone, sampled from two quarries ("Čertovy schody”) in the vicinity of Zlatý Kůn̆ Hill which lies $1 \mathrm{~km}$ south of the Bohemian village of Koněprusy (ca $30 \mathrm{~km}$ south-west of Prague, the Czech Republic; see Ernst \& May 2009). The upper Koněprusy Limestone is middle Pragian in age and can be assigned to the kindlei Conodont Zone (Slavík 1998, May 2005, pp. 120-124) in the standard conodont zonation or to the serratus Conodont Zone in the alternative conodont zonation of Slavík (2004). The biota of the reef is dominated by crinoids and bryozoans, followed by algae, brachiopods and corals (Flajs \& Hüssner 1996). The reef is composed mainly of white, well-washed boundstones and grainstones, which contain whole-bodied fossils.

Bryozoans were investigated in thin sections using a transmitted light binocular microscope. The thin sections and hand-specimens are housed in the Geological Centrum Göttingen, Germany, under collection numbers GZG.IN.0.010.558a, e, f, j, k, m, s, t, v, GZG.IN.0.010.557a-c.

\section{Systematic palaeontology}

Phylum Bryozoa Ehrenberg, 1831

Class Stenolaemata Borg, 1926

Order Cryptostomata Vine, 1884

Suborder Rhabdomesina Astrova \& Morozova, 1956

Family Hyphasmoporidae Vine, 1885

\section{Genus Petaloporella Prantl, 1935}

1935 Petaloporella Prantl, pp. 4, 5.

1966 Streblotrypa Vine. - Owen, p. 143 (pars). 
1970 Leptotrypella Vinassa. - Astrova, pp. 199, 200, pl. 7, figs $1 \mathrm{a}-\mathrm{c}$.

1983 Petaloporella Prantl. - Blake, p. 591.

1992 Petaloporella Prantl. - Gorjunova, p. 125.

1994 ?hyphasmoporid cryptostome; Bigey, pp. 15, 16.

1996 Streblotrypa (Streblotrypa) Vine. - Wyse Jackson, p. 136.

2005 Streblotrypa (Streblotrypa) Vine. - Ernst, p. 56.

Type species. - Petaloporella bohemica Prantl, 1935. "Braník" Limestone, Zlíchovian (Lower Emsian), Lower Devonian; Braník, the Czech Republic.

Emended diagnosis. - Branched colonies; autozooecia tubular, growing from the median axis, having subtriangular shape in transversal section in endozones, becoming circular to oval in exozones; hemisepta absent; metazooecia abundant, separating autozooecia in 1-3 rows; acanthostyles small, rare to abundant, sometimes absent.

Comparison. - Petaloporellais similar to Hyphasmopora Etheridge, 1875, but differs from it in the absence of hemisepta and presence of styles. Petaloporella is also similar to Streblotrypa (Streblotrypa) Vine, 1885, from which it differs in budding of autozooecia from the median axis instead of forming an axial bundle, as well as in the absence of hemisepta.

Occurrence. - Three species are assigned to Petaloporella: $P$. bohemica Prantl, 1935 from the Pragian and Lower Emsian (Lower Devonian) of the Czech Republic and from the Pragian of Morocco, P. pectinata (Owen, 1966) from the Lower Carboniferous of England, Ireland and Germany, and $P$. remota Gorjunova, 1992 from the Upper Carboniferous of northeastern Russia.

\section{Petaloporella bohemica Prantl, 1935}

\section{Figure 1A-H, Table 1}

1935 Petaloporella bohemica Prantl, pp. 5, 6, pl. 1, figs 4-6, text-figs 1-3.

1970 Leptotrypella multifora Astrova, pp. 199-200, pl. 7, figs $1 \mathrm{a}-\mathrm{c}$.

1994 ?hyphasmoporid cryptostome; Bigey, pp. 15, 16, pl. 1, figs $1-8$, figs $1-5,9-14$.

Type material. - Type specimens of Prantl (1935) are missing from the National Museum in Prague (Blake 1983, p. 591, and own revision). As a result, specimen number GZG.IN.0.010. 558a from the Koněprusy Limestone, Pragian (Lower Devonian); Zlatý Kůn̆, the Czech Republic is herein designated as the neotype of Petaloporella bohemica Prantl, 1935. The holotype of Leptotrypella multifo-
Table 1. Measurement statistics for Petaloporella bohemica Prantl, 1935 (twelve colonies), upper Koněprusy Limestone, middle Pragian (Lower Devonian) of Zlatý Kůn̆, the Czech Republic. Measurements are in mm. Abbreviations: $\mathrm{N}$ - number of measurements, $\mathrm{X}-$ mean, SD - sample standard deviation, CV - coefficient of variation, MIN minimal value, MAX - maximal value.

\begin{tabular}{lcccccc}
\hline & $\mathrm{N}$ & $\mathrm{X}$ & $\mathrm{SD}$ & $\mathrm{CV}$ & $\mathrm{MIN}$ & $\mathrm{MAX}$ \\
\hline branch width & 8 & 1.36 & 0.269 & 19.75 & 1.05 & 1.72 \\
$\begin{array}{l}\text { aperture width } \\
\begin{array}{l}\text { aperture spacing from } \\
\text { centre to centre }\end{array}\end{array}$ & 30 & 0.11 & 0.014 & 12.93 & 0.08 & 0.14 \\
$\begin{array}{l}\text { metazooecia width } \\
\text { acanthostyle diameter }\end{array}$ & 20 & 0.23 & 0.042 & 18.29 & 0.17 & 0.29 \\
\hline
\end{tabular}

ra Astrova, 1970 is deposited in the Paleontological Institute Moscow (PIN 2960/5).

Studied material. - GZG.IN.0.010.558a, e, f, j, k, m, s, t, v, GZG.IN.0.010.557a-c [Koněprusy Limestone, Pragian (Lower Devonian); Zlatý Kůn̆, the Czech Republic].

Description. - Ramose branched colonies. Branches $1.05-1.72 \mathrm{~mm}$ in diameter, with $0.30-0.38 \mathrm{~mm}$ wide exozones. Autozooecia tubular, growing from the median axis and bending gently in the exozones, the subtriangular shape in transverse section of the endozones becomes rounded in the exozones. Autozooecial apertures circular to oval, arranged in irregular rows on the colony surface. Hemisepta absent; rare planar diaphragms present. Abundant metazooecia separating autozooecia in 1-3 rows, arranged in a random order, rounded, restricted to the exozones. Autozooecial walls granular, $0.010-0.015 \mathrm{~mm}$ thick in endozones; laminated, $0.025-0.035 \mathrm{~mm}$ thick in exozones. Acanthostyles are small and rare, originating at the base of the exozones, and having distinct hyaline cores and laminated sheaths.

Comparison. - Leptotrypella multifora Astrova, 1970 does not belong to the trepostome genus Leptotrypella Vinassa de Regny, 1921, which is characterised by having few exilazooecia but many acanthostyles. This bryozoan taxon is synonomised herein with P. bohemica. Streblotrypa (Streblotrypa) pectinata Owen, 1966 from the Lower Carboniferous (Viséan) of England, Ireland and Germany, is generally similar, but differs in having more abundant acanthostyles (Owen 1966, Wyse Jackson 1996, Ernst 2005).

Occurrences. - Pragian (Lower Devonian); Khemis-n’ Ga, Morocco (Bigey 1994). Upper Koněprusy Limestone, middle Pragian (Lower Devonian); Zlatý Kůn̆, the Czech Republic (Astrova 1970, and present paper). Braník Limestone, lower Emsian (Lower Devonian); Braník, the Czech Republic (Prantl 1935). 

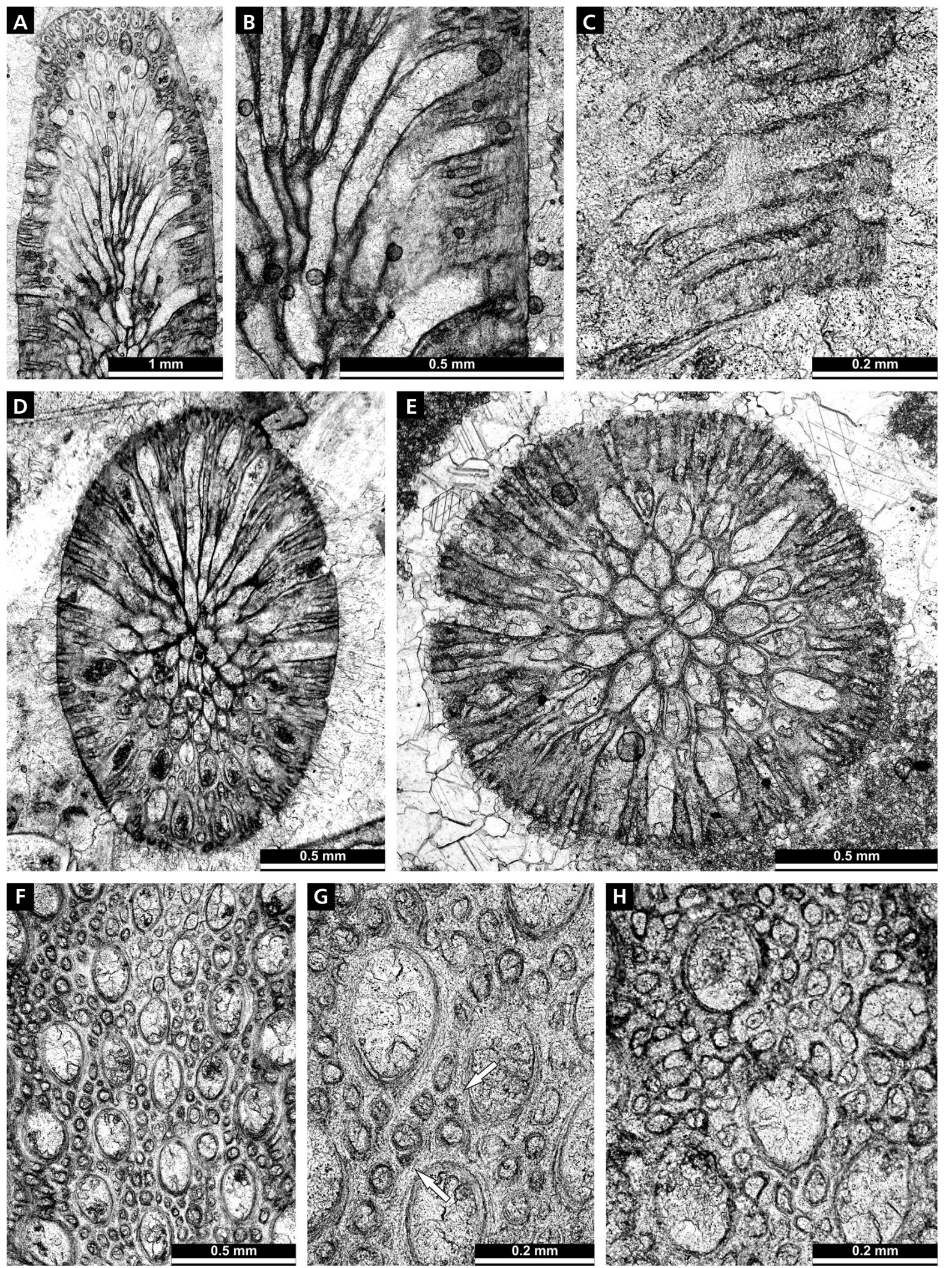

Figure 1. Petaloporella bohemica Prantl, 1935. All specimens from the upper Koněprusy Limestone, middle Pragian (Lower Devonian) of Zlatý Kůň, the Czech Republic. • A, B - branch, longitudinal section, neotype GZG.IN.0.010.558a. $\bullet$ C - branch, longitudinal section of the exozone showing metazooecia, GZG.IN.0.010.558e. $\bullet$ D - branch, oblique section, GZG.IN.0.010.558k. $\bullet$ E - branch, transverse section, GZG.IN.0.010.557b. $\bullet$ F, G - branch, tangential section showing autozooecial apertures, metazooecia and acanthostyles (arrows), GZG.IN.0.010.558j • H - branch, tangential section, GZG.IN.0.010.557a. 


\section{Discussion}

Bryozoa are abundant and diverse in the Devonian worldwide (Cuffey \& McKinney 1979). However, their use for stratigraphy and palaeobiogeographic studies is limited due to insufficient investigation of regional faunas. Indeed, bryozoans can be reliable indicators of environmental conditions and useful for palaeobiographic analysis. The finding of Petaloporella bohemica and another rhabdomesine cryptostome species, Paracuneatopora striata Ernst, 2008, in the Lower Devonian of Morocco (Bigey 1994) suggests a close relationship between these two areas. However, Pragian and Emsian bryozoan communities of Spain rarely contain Bohemian species (unpublished data). This suggests a low faunal exchange between Bohemian and Iberian communities in the Lower Devonian.

\section{Acknowledgements}

I am thankful to Mike Reich, Geological Centrum Göttingen, for providing the material for study, and Kamil Zágoršek, National Museum, Prague, for help with collection of Bohemian bryozoans. Patrick Wyse Jackson, Trinity College, Dublin, and Hans Arne Nakrem, Natural History Museum, Oslo, are also thanked for their helpful reviews and comments on the manuscript. The present study was accomplished within the project ER 278/4-1 u. 2, supported by the Deutsche Forschungsgemeinschaft (DFG). This paper is a contribution to IGCP 499 "Devonian land-sea interaction: evolution of ecosystems and climate". A short field trip and work on the collections of National Museum in Prague were supported by the grant DE06P04OMG009.

\section{References}

Astrova, G.G. 1970. Early Devonian trepostomatous bryozoans from Czechoslovakia. Paleontologicheskii Zhurnal 4(2), 197-201. [in Russian]

AStrovA, G.G. \& MOROZOVA, I.P. 1956. Systematics of the order Cryptostomata. Doklady Akademii Nauk SSSR 110, 661-664. [in Russian]

BIGEY, F.P. 1994. Bryozoans as components of a Devonian fauna in the Safi area (Morocco), 15-21. In HAYWARD, P.J., RYLAND, J.S. \& TAYLOR, P.D. (eds) Biology and Palaeobiology of Bryozoans. Olsen \& Olsen, Fredensborg.

BlaKe, D.B. 1983. The Order Cryptostomata. Systematic descriptions for the Suborder Rhabdomesina, 551-592. In ROBISON, R.A. (ed.) Treatise on invertebrate paleontology, Part $G$ (1). Bryozoa (revised). Geological Society of America \& University of Kansas Press, Boulder \& Lawrence.

BorG, F. 1926. Studies on recent cyclostomatous Bryozoa. Zoologiska Bidrag fran Uppsala 10, 181-507.

CufFEY, R.J. \& MCKInNEY, F.K. 1979. Devonian Bryozoa. Special Papers in Palaeontology 23, 307-311.

EHRENBERG, C.G. 1831. Animalia invertebrata exclusis insects. Symbolae Physicae, seu Icones et descriptiones Corporum
Naturalium novorum aut minus cognitorum. Pars Zoologica. 831 pp. Mittler, Berlin.

ERNST, A. 2005. Lower Carboniferous Bryozoa from some localities in Sauerland, Germany, 49-62. In MoYANO, G.I., CANCINO, J.M. \& WYSE JACKSON, P.N. (eds) Bryozoan Studies 2004 - Proceedings of the $13^{\text {th }}$ International Bryozoology Association Conference, Concepcion, Chile, January 2004. Balkema Publishing House, Leiden, London, New York.

ERNST, A. 2008. Trepostome and cryptostome bryozoans from the Koněprusy Limestone (Lower Devonian, Pragian) of Zlatý Kůň (Czech Republic). Rivista Italiana di Paleontologia $e$ Stratigrafia 114(3), 329-348.

ERNST, A. \& MAY, A. 2009. Bryozoan fauna from the Koněprusy Limestone (Pragian, Lower Devonian) of Zlatý Kůň near Koněprusy (Czech Republic). Journal of Paleontology 83(5), 767-782. DOI 10.1666/09-019.1

ETHERDGE, R. 1875. Note on a new provisional genus of Carboniferous Polyzoa. Annals and Magazine of Natural History (4)15, $43-45$.

FlAJS, G. \& HÜSSNER, H. 1996. Lower Devonian coral/stromatoporoid reefs in the Koněprusy area (Czech Republic) - A preliminary report, 355-357. Göttinger Arbeiten zur Geologie und Paläontologie, Sb2.

GoRJunOVA, R.V. 1992. Morphology and systematics of the Paleozoic Bryozoa. Trudy Paleontologicheskogo Instituta, R. A. N. 251, 1-168. [in Russian]

MAY, A. 2005. Die Stromatoporen des Devons und Silurs von Zentral-Böhmen (Tschechische Republik) und ihre Kommensalen. Zitteliana B25, 117-250.

MCKInNEY, F.K. \& KŘíž, J. 1986. Lower Devonian Fenestrata (Bryozoa) of the Prague Basin, Barrandian Area, Bohemia, Czechoslovakia. Fieldiana, Geology new series 15, 1-90.

OWEN, D.E. 1966. New Carboniferous Polyzoa from Derbyshire. Geological Journal 5(1), 135-148.

PRANTL, F. 1935. New cyclostomatous Bryozoa from BraníkLimestone $\mathrm{g}_{\alpha}$ (Bohemia). Bulletin international de l'Academie des Sciences de Boheme 36, 1-10.

SLAVíK, L. 1998. Early Devonian conodont succession from the section of the Čertovy schody Quarry (Koněprusy, Barrandian, Czech Republic). Věstník Českého geologického ústavu 73, $157-172$.

SLAVÍK, L. 2004. A new conodont zonation of the Pragian Stage (Lower Devonian) in the stratotype area (Barrandian, central Bohemia). Newsletters on Stratigraphy 40(1/2), 39-71. DOI 10.1127/0078-0421/2004/0040-0039

VINE, G.R. 1884. Fourth report of the Committee appointed for the purpose of reporting on fossil Polyzoa. Reports of the $53^{\text {rd }}$ meeting of the British Association for Advances in Science, 161-209.

VINE, G.R. 1885. Notes on the Polyzoa and Foraminifera of the Cambridge Greensand. Proceedings of the Yorkshire Geological Society 9, 10-29.

VINASSA DE REGNY, P. 1921. Sulla classificazione die trepostomidi. Societa Italiana di Scienze Naturali Atti 59, 212-231.

WYSE JACKSON, P.N. 1996. Bryozoa from the Lower Carboniferous (Viséan) of County Fermanagh, Ireland. Bulletin of the Natural History Museum, London (Geology) 52(2), 119-171. 